\title{
Kepercayaan Politik dan Partispasi Politik Pemilih Pemula
}

\author{
Lusy Asa Akhrani, Fitsabilla Imansari, Faizah \\ lusyasa@ub.ac.id \\ Jurusan Psikologi, Universitas Brawijaya, Malang, Indonesia
}

\begin{abstract}
This research aimed to examine the relationship between political trust and political participations among young voters. One hundred and five young voters participated in this quantitative study, sampled by using non-probability sampling (purposive sampling). Data were collected by using Political Trust Scale and Political Participation Scale, both developed by Akhrani (2016). Data obtained from this study were then analysed by using Pearson's Product Moment technique. The result showed that significant correlation between political trust and political participation do exist $(r=0.296, n=105, p=0.002)$. This result implies that the higher the political trust is, the higher the political participation will be. This study have practical implication that votes from young voters matter significantly for political party as they constitute $20 \%$ of overall voters. Therefore, in order to win young voters' vote, government and political parties should improve their political performance.
\end{abstract}

Keywords: political trust; political participation; young voters

Penelitian ini bertujuan untuk melihat hubungan antara kepercayaan politik dengan partisipasi politik pada pemilih pemula. Responden dalam penelitian yang menggunakan pendekatan kuantitatif ini adalah 105 orang pemilih pemula, yang diperoleh dengan menggunakan teknik non probability sampling (purposive sampling). Data dikumpulkan dengan menggunakan Skala Kepercayaan Politik dan Skala Partisipasi Politik dari Akhrani (2016). Analisis data penelitian ini menggunakan teknik Product Moment dari Pearson. Hasil dari penelitian ini menunjukkan bahwa terdapat hubungan yang signifikan antara kepercayaan politik dengan partisipasi politik $(r=0.296, n=105, p=0.002)$. Hal ini bermakna semakin tinggi kepercayaan politik maka akan semakin tinggi pula partisipasi politiknya. Penelitian ini memberikan implikasi praktis bahwa suara para pemilih pemula sangat penting bagi partai politik karena jumlahnya yang mencapai $20 \%$ dari keseluruhan suara pemilih. Dengan demikian, untuk mendapatkan suara para pemilih pemula, pemerintah dan partai politik harus memperbaiki kinerja politiknya.

Kata kunci: kepercayaan politik; partisipasi politik; pemilih pemula

Received: January 24, 2018 Accepted: May 4, 2018

How to cite: Akhrani, L. A., Imansari, F., \& Faizah. (2018). Kepercayaan politik dan partispasi politik pemilih pemula. MEDIAPSI, 4(1), 1-6. doi: https://doi.org/10.21776/ub.mps.2018.004.01.1

\section{Pendahuluan}

Partisipasi politik merupakan suatu kegiatan seseorang atau sekelompok orang untuk ikut secara aktif dalam kehidupan politik yaitu dengan cara memilih pimpinan negara yang secara langsung atau tidak langsung memengaruhi kebijakan pemerintah. Selain itu partisipasi politik juga mencakup tindakan seperti memberikan suara dalam pemilihan umum, menghadiri rapat umum, menjadi anggota suatu partai atau kelompok kepentingan, mengadakan hubungan dengan pejabat pemerintah atau anggota parlemen (Budiardjo, 2010). Menurut McClosky (1968) partisipasi politik dapat diartikan sebagai kegiatan sukarela dari warga masyarakat, yang mana mereka mengambil bagian dalam proses pemilihan penguasa dan secara langsung atau tidak langsung dalam proses pembentukan kebijakan umum.

Menurut Almond (1950) bentuk-bentuk partisipasi politik dapat dibedakan menjadi 
dua, yaitu konvensional dan nonkonvensional. Partisipasi politik secara konvensional merupakan bentuk kegiatan partisipasi politik yang normal dalam negara demokrasi di mana prosedur dan waktu partisipasinya diketahui publik secara pasti oleh semua warga, misalkan pemberian suara (voting), diskusi politik, kegiatan kampanye, membentuk atau bergabung dengan kelompok kepentingan, dan komunikasi individual dengan pejabat politik. Partisipasi politik yang nonkonvensional sendiri merupakan bentuk kegiatan partisipasi politik yang legal maupun ilegal, di mana prosedur dan waktu partisipasi ditentukan sendiri oleh anggota masyarakat yang melakukan partisipasi itu sendiri seperti, pengajuan petisi, berdemonstrasi, mogok dan konferensi, tindakan kekerasan politik terhadap manusia, perang gerilya, dan revolusi.

Tabel 1

Tingkat Partisipasi Politik dalam Pemilu di Indonesia

\begin{tabular}{ccc}
\hline Pemilu & $\begin{array}{c}\text { Tingkat Partisipasi } \\
\text { Politik (\%) }\end{array}$ & $\begin{array}{c}\text { Nonpartisipasi } \\
(\%)\end{array}$ \\
\hline 1995 & 91.4 & 8.6 \\
1971 & 96.6 & 3.4 \\
1997 & 96.5 & 3.5 \\
1982 & 96.5 & 3.5 \\
1987 & 96.4 & 3.6 \\
1992 & 95.1 & 4.9 \\
1997 & 93.6 & 6.4 \\
1999 & 92.6 & 7.3 \\
Pileg 2004 & 84.1 & 15.9 \\
Pilpres I & 78.2 & 21.8 \\
Pilpres II & 76.6 & 23.4 \\
2009 & 71.7 & 28.3 \\
2014 & 75.2 & 24.8 \\
\hline
\end{tabular}

Tabel diolah dari Pratomo \& Firdaus (2014)

Tabel 1 menjelaskan tentang tingkat partisipasi politik dan nonpartisipasi pada pemilihan umum di Indonesia mulai tahun 1955 sampai tahun 2014. Tabel tersebut menjelaskan bahwa pemilihan umum di Indonesia mengalami penurunan partispasi politik yang ditandai dengan meningkatnya angka nonpartisipasi. Partisipasi politik mengalami kenaikan pada tahun 2014 dengan angka partisipasi $75.2 \%$, naik $3.5 \%$ dari tahun sebelumnya.

Pemilih di Indonesia dapat dibagi menjadi tiga kategori. Pertama, pemilih rasional, yakni pemilih yang benar-benar memilih partai berdasarkan penilaian dan analisis mendalam. Kedua, pemilih kritis emosional, yakni pemilih yang masih idealis dan tidak kenal kompromi. Ketiga, pemilih pemula, yakni pemilih yang baru pertama kali memilih karena usia mereka baru memasuki usia pemilih (Yuningsih \& Warsono, 2014).

Menurut Paige (1991), yang menentukan tinggi rendahnya partisipasi politik seseorang adalah kesadaran politik serta kepercayaan terhadap pemerintah atau sistem politik. Kepercayaan politik adalah suatu orientasi evaluatif masyarakat terhadap sistem politik atau bagian dari sistem politik atau bagian dari sistem tersebut yang berdasarkan pada harapan normatif (Hetherington, 1998). Menurut Miller and Listhaug (1990), kepercayaan politik merupakan pusat dari teori demokrasi di mana hal tersebut mencerminkan evaluasi apakah otoritas politik dan lembaga yang melakukannya sesuai dengan harapan normatif yang dimiliki oleh publik.

Berdasarkan uraian tersebut, terdapat keterkaitan antara partisipasi politik dan kepercayaan politik. Oleh karena itu, penulis tertartik untuk melihat sejauh mana kepercayaan politik dan partisipasi politik saling berhubungan terutama dalam konteks pemilih pemula. 


\section{Metode}

\section{Desain penelitian}

Penelitian ini merupakan penelitian yang menggunakan pendekatan kuantitatif korelasional, yang bertujuan untuk mengetahui hubungan antara satu variabel dengan variabel lainnya.

\section{Partisipan}

Penelitian ini melibatkan seluruh pemilih pemula di Kota Malang, sedangkan sampel penelitian ini diambil dengan menggunakan teknik purposive sampling. Pemilihan sampel dengan menggunakan teknik purposive sampling bertujuan untuk mendapatkan sampel dengan karakteristik yang diinginkan, yaitu (1) siswa yang berdomisili di Kota Malang, (2) berusia 17-21 tahun, dan (3) belum pernah menggunakan hak pilihnya pada pemilihan sebelumnya. Peneliti mendapatkan sampel sebanyak 105 siswa yang terdiri dari 46 siswa laki- aki dan 59 siswa perempuan.

\section{Instrumen penelitian}

Pengambilan data pada penelitian ini menggunakan skala. Adapun skala penelitian yang digunakan pada penelitian ini terdiri dari Skala Kepercayaan Politik dan Skala Partisipasi Politik. Skala tersebut dimodifikasi dari penelitian Akhrani (2016) yang mengacu pada penjelasan Lewicki, McAllister, \& Bies (1998) yang meliputi dimensi ability, integrity dan benevolence dengan jumlah delapan butir. Hasil uji coba Skala Kepercayaan Politik menunjukkan bahwa alat ukur tersebut dinilai valid dan reliabel dengan koefisien reliabilitas sebesar 0.707. Sementara itu, Skala Partisipasi Politik mengadaptasi dari penelitian sebelumnya milik Akhrani (2016) yang mengacu pada penjelasan Bratton (2009) yang meliputi delapan dimensi yaitu interest in politics, discuss politics, belong voluntary organization, vote in last election, contacted government officials, contacted elected officials, contacted tradisional leader, dan protest or demontrated dengan jumlah tujuh belas butir. Hasil uji coba Skala Partisipasi Politik menunjukkan bahwa alat ukur tersebut dinilai valid dan reliabel dengan koefisien reliabilitas sebesar 0.831 .

\section{Teknik analisis data}

Uji hipotesis penelitian ini dilakukan dengan teknik korelasional Product Moment dari Pearson dengan menggunakan bantuan SPSS versi 20. Sebelumnya, terlebih dahulu dilakukan uji asumsi yang terdiri dari uji normalitas dan uji linearitas.

\section{Hasil}

\section{Uji asumsi (normalitas dan linearitas)}

Uji normalitas dengan menggunakan teknik Kolmogorov-Smirnov menunjukkan bahwa variabel kepercayaan politik memiliki tingkat normalitas sebesar 0.066 , sedangkan variabel partisipasi politik sebesar 0.872 . Dapat disimpulkan bahwa kedua variabel penelitian ini terdistribusi secara normal (keterangan selengkapnya dapat dilihat di Tabel 2).

Tabel 2

Hasil Uji Normalitas

\begin{tabular}{lcc}
\hline Variabel & Kolmogrov-Smirnov & Sig. \\
\hline $\begin{array}{l}\text { Kepercayaan } \\
\text { politik }\end{array}$ & 1.305 & 0.066 \\
\hline $\begin{array}{l}\text { Partisipasi } \\
\text { politik }\end{array}$ & 0.594 & 0.872 \\
\hline
\end{tabular}

Sementara itu, test for linearity menunjukkan bahwa variabel kepercayaan politik dan partisipasi politik memiliki hubungan yang linier dengan nilai signifikansi sebesar 0.933 (keterangan selengkapnya dapat dilihat di Tabel 3 dan Gambar 1). 
Tabel 3

Hasil Uji Linearitas

\begin{tabular}{lcc}
\hline \multicolumn{1}{c}{ Variabel } & F & Sig. \\
\hline $\begin{array}{l}\text { Kepercayaan } \\
\text { politik*Partisipasi } \\
\text { politik }\end{array}$ & 0.460 & 0.933 \\
\hline
\end{tabular}

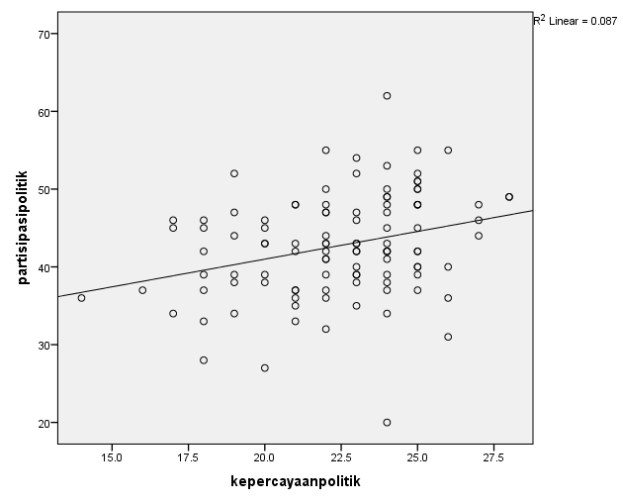

Gambar 1. Plot Hasil Uji Linearitas

\section{Uji hipotesis}

Hasil uji hipotesis sebagaimana ditunjukkan pada Tabel 3 menunjukkan bahwa korelasi antar variabel kepercayaan politik dan partisipasi politik pada pemilih pemula adalah signifikan ( $\mathrm{r}=0.296, \mathrm{n}=105, \mathrm{p}=0.002)$, dengan angka korelasi pada tingkat sedang.

Tabel 3

Hasil Uji Hipotesis

\begin{tabular}{lrrr}
\hline \multicolumn{1}{c}{ Variabel } & r & Sig. & R \\
\hline $\begin{array}{l}\text { Kepercayaan } \\
\text { politik*Partisipasi } \\
\text { politik }\end{array}$ & 0.296 & 0.002 & $8.8 \%$ \\
\hline
\end{tabular}

\section{Diskusi}

Penelitian ini bertujuan untuk melihat hubungan antara kepercayaan politik dengan partisipasi politik pada pemilih pemula. Berdasarkan uji hipotesis, diperoleh hasil bahwa korelasi kedua variabel tersebut signifikan ( $r=0.296, \mathrm{n}=105, \mathrm{p}=0.002)$. Hal tersebut menunjukkan semakin tinggi kepercayaan politik maka semakin tinggi pula partisipasi politik pada pemilih pemula.
Demikian pula sebaliknya, semakin rendah kepercayaan politik, maka semakin rendah pula partisipasi politik.

Hasil penelitian ini sejalan dengan hasil penelitian yang dilakukan oleh Wahyudi, dkk (2013) tentang kepercayaan politik, kepuasan demokrasi serta partisipasi politik di mana peneliti menggunakan mahasiswa sebagai sampel. Sampel tersebut merupakan pemilih pemula tetapi dengan tingkat pendidikan yang berbeda. Hasil penelitian tersebut menunjukkan bahwa kepercayaan politik dan kepuasan demokrasi berperan penting dalam partisipasi politik mahasiswa. Penelitian tentang kepercayaan politik juga dilakukan oleh Marien (2011) yang bertujuan untuk melihat apakah terdapat pengaruh hasil pemilihan politik pada kepercayaan politik dengan melihat analisis multilevel pada dua puluh tiga negara. Hasil penelitian itu menunjukkan bahwa terdapat kepercayaan politik tinggi ketika hasil dari pemilihan politik tersebut proporsional. Sebaliknya, jika negara tersebut tidak proporsional dalam pemilihan politik maka kepercayaan politiknya semakin rendah.

Hal yang sama juga diungkapkan pada penelitian dari Suh, Yee, dan Chang (2013) yang melihat jenis-jenis kepercayaan dan partisipasi politik di lima negara yang menghasilkan temuan bahwasannya lembagalembaga yang berorientasi pada jenis kepercayaan akan lebih cenderung untuk berpartisipasi dalam mengekspresikan opini mereka kepada pemerintah, berkampanye politik, dan berdemonstrasi. Penelitian yang dilakukan oleh Akhrani (2016) juga melihat peranan kepercayaan politik untuk berpartisipasi politik di Jawa Timur. Berbeda dengan penelitian-penelitian sebelumnya, berdasarkan penelitian tersebut, ditemukan 
bahwa terdapat pengaruh negatif antara kepercayaan politik dengan partisipasi politik. Hal tersebut menunjukkan bahwa semakin seseorang percaya terhadap politik maka orang itu justru akan cenderung tidak berpartisipasi dalam politik.

Menurut Kumlin (2002), apabila pengalaman langsung seseorang ataupun individu terhadap pemilihan umum maupun kegiatan demokrasi lainnya sebagian besar dipersepsi baik, maka individu tersebut akan lebih cenderung percaya. Berdasarkan dari perhitungan data hipotetik penelitian ini, variabel kepercayaan politik pada pemilih pemula tergolong sedang. Hal ini disebabkan pemilih pemula yang dijadikan sampel oleh peneliti merupakan pemilih pemula yang usianya rata-rata berumur 17-18 tahun, di mana belum ada pengalaman dalam pemilihan politik. Berdasarkan penelitian ini pula, diketahui bahwa kepercayaan politik dan partisipasi politik berkorelasi. Hal tersebut dikarenakan partisipasi politik yang dimiliki oleh pemilih pemula dipengaruhi oleh faktor internal dan eksternal, yang salah satunya adalah psikologi kognitif dan juga faktor sosial dan politik. Faktor-faktor tersebut berkaitan erat dengan kepercayaan politik sehingga memunculkan hubungan antara kedua variabel tersebut.

Keterbatasan dalam penelitian ini adalah partisipan penelitian yang usianya hanya berada pada rentang 17-18 tahun dan bersekolah, sedangkan partisipan yang berada pada usia pemilih pemula namun tidak bersekolah tidak diikutsertakan pada penelitian ini. Oleh karena itu, saran untuk penelitian selanjutnya adalah agar mengambil sampel dengan rentang usia yang lebih luas, seperti 17-21 tahun, dan mempertimbangkan latar belakang pendidikan yang lebih beragam.

\section{Daftar Pustaka}

Akhrani, L.A. (2016). Model partisipasi politik ditinjau dari kesadaran politik, kepercayaan politik, orientasi nilai sosial, dan sikap politik pemilih di Jawa Timur. Disertasi (tidak diterbitkan). Surabaya: Universitas Airlangga.

Almond, G.A. (1950). The American people and foreign policy. New York: Harcourt, Brace, and Company

Bratton, M. (2009, July). Democratic attitudes and political participation: An exploratory comparison across world regions. Paper presented at Congress of the International Political Science Association, Michigan State University, USA. Diambil dari http://paperroom.ipsa.org/papers/paper 1542.pdf

Budiardjo, M. (2010). Dasar-dasar Ilmu Politik Edisi Revisi. Jakarta: Gramedia Pustaka Utama.

Hetherington, M. J. (1998). The political relevance of political trust. American Political Science Review, 92(4), 79-808. doi: https://doi.org/10.2307/2586304

Kumlin, S. (2002). Institutions-experiencespreferences: how welfare state design affect political trust and ideology. Dalam B. Rothstein \& S. Steinmo (Eds.), Restructuring The Welfare State (hal. 20-50). London: Palgrave.

Lewicki, R. J., McAllister, D. J., \& Bies, R. J. (1998). Trust and distrust: New relationships and realities. Academy of Management Review, 23(3), 438-458. doi: https://doi.org/10.2307/259288

Marien, S. (2011). The effect of electoral outcomes on political trust: A multi-level 


\section{KEPERCAYAAN POLITIK}

analysis of 23 countries. Journal Electoral Studies, 4(30), 712-726. doi: https://doi.org/10.1016/j.electstud.2011. $\underline{06.015}$

McClosky, H. (1968). International Encyclopedia of the Social Sciences. New York: Macmillan and Free Press.

Miller, A. H., \& Listhaug, O. (1990). Political parties and confidence in government: A comparison of Norway, Sweden and the United States. British Journal of Political Science, 20(3), 357-386. doi: https://doi.org/10.1017/S000712340000 $\underline{5883}$

Paige, J. M. (1991). Coffee and Power: Revolution and the Rise of Democracy in Central America. Cambridge, MA: Harvard University Press.

Pratomo, Y., \& Firdaus, R. F. (2014). Ini tingkat partisipasi pemilih dari Pemilu 1955-2014. Diambil dari https://www.merdeka.com/politik/initingkat-partisipasi-pemilih-dari-pemilu$\underline{\text { 1955-2014.html }}$

Suh, H., Yee, J., \& Chang, D. (2013). Type of trust and political participation in five countries: Results of social quality survey. Development and Society, 42(1), $1-28$. doi: https://doi.org/10.21588/dns.2013.42.1. $\underline{001}$

Wahyudi, H., Fernando, T., Ahmad A., Khairani A., Fatimah, Agung, I. M., \& Milla, M. N. (2013). Peran kepercayaan politik dan kepuasan demokrasi terhadap partisipasi politik mahasiswa. Jurnal Psikologi, 9(2), 94-99. Diambil dari http://ejournal.uinsuska.ac.id/index.php/psikologi/article/v $\underline{\text { iew/171 }}$
Yuningsih, N. A. I \& Warsono (2014). Partisipasi politik remaja (pemilih pemula) pada Pemilukada Mojokerto tahun 2010 di Desa Sumber Tanggul Kecamatan Mojosari Kabupaten Mojokerto. Kajian Moral dan Kewarganegaraan, 1(2), 16-30. Diambil dari http://jurnalmahasiswa.unesa.ac.id/inde x.php/jurnal-pendidikankewarganegaraa/article/view/6688 